\title{
Communicating Museums: A Textual Analysis of Content and Interaction Management
}

\section{Monica Bîră}

\begin{abstract}
Museums, through their institutional discourses, are playing an important but sometimes neglected role in enforcing social practices and creating social identities. With the new digital era, museums had to adapt to new forms of communication: in an environment that, at least, gives everybody an equal voice, museums managed to communicate themselves without renouncing their position of depositaries of knowledge and authority. By analyzing online communication, through content management and interaction management (on websites, Facebook pages) the current study aims to explore the mechanisms enabling museums to convey information about their specific features (space, access, learning and interpreting) while retaining a main role not only as communicators, but also as actors reinforcing the larger system of beliefs and knowledge that govern what counts as right or wrong, good or bad, normal or abnormal, in a particular society. Thus, by combining communication seen as a management tool and textual analysis, this study illustrates the application of diverse qualitative research methods in the fields of management, and, specifically, in the field of communication management.
\end{abstract}

Keywords: toys museum, communication management, content management, textual analysis.

\section{INTRODUCTION}

Museums, like so many institutions that are shaping our representations of the world and our education related to everything from history to science - are creations of the 19th century. In a broad sense, their mission - at least in Europe - was defined two centuries ago, reflecting the priorities of western

1 Monica Bira, Ph.D., National University of Political Studies and Public Administration/Bvd. Expozitiei, No. 30 A, Bucharest, Romania, e-maill: monica.bira@comunicare.ro

Received 22 November 2017; Revised 25 May 2018, 10 September 2018; Accepted 17 September 2018 
societies (Poulot, 2009) and of societies going through a westernization process, as was the case in Central and South-Eastern Europe.

Basically, a museum was a depositary of things considered to be 'important': artifacts coming from long-lost empires or from the more recent past (e.g. archaeology museums, art museums), representative items related to natural history (natural history museums), or items documenting a way of life, an extinct culture or a culture about to become extinct (e.g. ethnographic museums). The primary purpose of creating a museum was to save all those items from being lost, but also to enable a more significant number of persons to benefit from making contact with past cultures and civilizations. Additionally, museums also had an essential role in research, especially by funding expeditions aimed at exploring nature or archaeological sites and by studying the objects thus acquired (Poulot, 2005). The role played by museums (all over Europe) as part of the national construction process should not be ignored, especially since, even today a significant number of museums in Eastern Europe are still tributary to this vision - either by the content of their collections or by the general frame of interpretation still in use.

The present study aims to explore how museums are nowadays managing communication by proposing a double angled perspective that addresses both the context of museum discourse (Richardson, 2007; Jones, 2002; Fairclough, 2003) and the way in which, through various strategies of content management and interaction management of online communication, a contemporary museum is still able to enforce social practices and to create social identities (Jones, 2012, p. 15).

\section{LITERATURE BACKGROUND}

\section{Toy museums and interactive online and offline communication}

Within the rather large family of museums, toys and children museums are a specific category and while it would be difficult to consider them as "underrepresented," over the time, they have been less interesting for scholars. Regardless of the theoretical perspective (whether it is history, museum studies or ethnography), studies dedicated to toy museums are usually pointing out the insufficient work done in this direction (Girveau \& Charles, 2011). Contrary to what one may think, toys are not so scarce within museum collections: a recent study pointed out that the number of items qualifying as "toys" would be significantly more critical within museum collections if some objects were to be reconsidered as to their function or use (Brookshaw, 2009).

Most studies that have focused on toy museums are adopting a historical perspective. They are aiming to document the slow process of transforming 
a somewhat marginal category of objects into a collection within its own right (Burton, 1997) or they propose an investigation into social representations related to toys and the societies producing them (Girveau \& Charles, 2011). Also, studying the portrayal of childhood and children through play objects, or studying the way in which different items dedicated to children were actually used - are expressing the same historical vision upon items contented in a toy museum (Brookshaw, 2009).

Museum studies, combining history and sociology, are proposing an approach based on acquiring a better knowledge about the specificity of collections (if we are thinking in terms of curatorship and museology) (Gilmore \& Rentschler, 2002). In some cases, they explore or merely illustrate the active role that museums play in shaping today's society (Mayfield, 2005), (Hooper Greenhill, 1992).

Toy museums are sharing a series of common challenges with "classical museums." However, given their specific collection and public, we assume them to be more inclined towards outreach activities and also to have a higher degree of visitor-oriented communication. Moreover, this regardless the fact that they are addressing a variety of public, just like "usual" museums and they also have to adapt their tone of voice and messages to different audiences such as educators, children, parents, grandparents, or other adults (simply as visitors).

Studies related to museums in the digital era are covering a large area, exploring the adaptation of museums to the computer era, both in term of collection management but also in terms of communication (Pary, 2010). (Liu, Liu, \& Lin, 2015). More specifically, previous studies are already pointing towards the limited use of web 2.0 tools when it comes to creating a more interactive and collaborative form of communication between museums and their audiences. For example, when analyzing content and interaction management, researchers determined that museums are not using the Internet as a bidirectional communication tool (Capriotti \& Kuklinski, 2012; Capriotti \& Gonzalez-Herrero, 2013; Badell, 2015).

\section{METHODOLOGY}

Taking into consideration that managing online communication is instrumental in building, shaping and maintaining a museum's relation with its audience, the current study aims to investigate the way in which content management and interaction management in online communication (via websites and Facebook pages) enable museums to strengthen the relationship with their audience. Using textual analysis (Duriau, Reger \& Pfarrer, 2007) to identify and 
to explore the functioning of museums' online communication contributes to a broader understanding of museum management: online communication management is a powerful instrument used not only to attract visitors but also to express and reinforce a museum's mission and role within society.

In order to asses online communication management, the study addressed two specific processes: content management (the way the content is displayed and organized, the language in which it is communicated) and interaction management (is the website providing interaction opportunities for the prospective visitors? What type of interaction is proposed? In what way is the Facebook page engaging audiences? What can be considered as interaction on Facebook?). Further, those two categories (content and interaction) were analyzed in connection with activities specific to the museum practice itself: defining a space, providing access, proposing an interpretation and facilitating learning. Exhibitions and objects were not included in this analysis because the purpose was to focus on the process of communication and not on its objects.

The analysis covers texts extracted from four Facebook pages and four websites managed by museums in Europe (two in France, one in Great Britain and one in Spain). All museums are a part of the extended family of toys museums and three of them are proper children museums. The selection is based on a previous survey targeting toys museums across Europe and the USA ${ }^{2}$. The main criteria of selection: to be a European based museum, to propose a variety of activities promoting visitor engagement and to be a registered museum in its specific country. However, since there is an increasing number of organizations that are calling themselves museums but are not "proper" museums (not according to the law, anyway) the analysis also includes such an establishment, which is more of an art gallery than a museum and which fits within two criteria: it is European based and it has a consistent policy of engaging with visitors.

These are the museums whose websites and Facebook pages were analyzed within the current study. (1) Art Ludique in Paris is a private initiative and, at least judging from its website and the Facebook page seems to be a thriving organization and an economic success. It is owned by a couple of French art-connoisseurs with previous experience within the world of art galleries, exhibitions and contemporary art. (2) Toy Museum / Musée du Jouet in Moirans-en-Montagne, Jura region, France is a museum perfectly fitting into the category of "classical museum": it has a valuable and significant collection, an institutional tradition (founded in the 1980s), an emblematic building and it engages with its community (3). Museo Valenciano del Jugete

2 Alexandra Zbuchea, Monica Bîră, Exploring the universe of toys - toys museums and collections in Europe and the USA, book chapter, to be published in 2017, in Romanian. 
(Alicante, Valencia region, Spain) also falls into the category of "classical museum" (established during the 1980s, it has its own collection). This museum is deeply rooted in the local tradition of toy manufacturing and its headquarters is located in a restored former toy manufacture dating back to the beginning of the 20th century. (4) The Victoria \& Albert Museum of Childhood Bethnal Green, in London was established during the late 19th century and it is today the UK's National Museum of Childhood and the largest institution of its kind in the world. The museum sees itself as an "international leader in engaging audiences in the material culture and experiences of childhood." To sum up: there are four museums, one of them is private, the other three are funded by the state and/or local collectivities; at least one museum is assuming and declaring a wide involvement with an international audience (The V\&A Museum of Childhood). Meanwhile, two are positioning themselves either by name or by policy as "regional museums." Art Ludique, although not nominally addressing an international audience, targets such visitors by its communication practices.

\section{MAIN FINDINGS}

The main findings of the present study are organized around two main themes: content management and interaction management which, in their turn, were explored by analyzing practices related to communication on the websites and Facebook pages. Within those specific categories of "content" and "interaction" I specifically followed how the interaction between the "voice" of the museum and the voices of its visitors are creating and referring to: space, access, interpretation \& learning - as basic categories related to museum activities.

It is important to mention that there are at least two levels in assessing every one of the above-mentioned characteristics and that both of them will be addressed. The first level is associated with tangible reality and is usually constructed by using narration, description and pictures. The second one is connected with virtual interaction and concerns the way in which a user is interacting with the museum but also with other users. This interaction is mediated mainly by text and sometimes by images (e.g., emoticons or images used by museums to advertise their activities).

\section{Constructing a space and a discourse about the world}

When referring to space, this is defined as a place where a specific interaction happens, or where communication is performed. Describing, presenting, 
narrating or showing that specific space to the visitor is contributing to construct a specific discourse. In the following paragraphs, the study explores what techniques are used by museum in order to define their space of action and, implicitly, the space of social interaction between them and the visitor.

Art Ludique, a new establishment, only refers to its space by naming its location within the city, mentioning the surrounding architecture and the general atmosphere. Words suggesting dynamism, progress and novelty are used, such as "innovation and avant-garde." Mentioning the Seine river ensures that every foreign tourist will associate the location of Art Ludique with an emblematic place of interest in Paris:

"The iconic avant-garde architecture of Les Docks - Cité de la Mode et du Design, is perfectly suited to the universe of Art Ludique. Overlooking the Seine in the southeast of Paris, in a resolutely innovative neighborhood, Les Docks offers both the space and location to receive thousands of visitors each year"3.

The other three museums, each one in its own way, are paying considerable attention to the building where their collections are on display. Their long or very long history, the economic costs involved in building, renovating or improving conditions and keeping everything up to date might by enough justification for making good use of the building in order to promote a general discourse about the museum and its place in a community/society. Museo Valenciano del Jugete uses narration as the main canvas for presenting its building. Meanwhile the Musée du Jouet in Moirans-en-Montagne uses a detailed description supported by narration; however, narration comes second.

Paying tribute to local traditions, the Museo Valenciano del Jugete highlights its location in an ancient factory, that underwent a long restoration process which was completed in 2013.

"Renovation work in the first stage of the project was done to the central bay area of the factory, dating back to 1912 that was rebuilt in 1962, and the workshops that were built in 1915. They were fitted out as the permanent exhibition area and the temporary exhibition room respectively. The definitive home for the museum was opened on the 29th of November, 2013"

The different years, 1912, 1915, and 1962, mentioned when narrating the museum history emphasize the importance attached to traditions, to

3 http://www.artludique.com/musee2.html accessed 01.10.2017

4 http://www.museojuguete.com/en/museum/ accessed on 01.10.2017 
continuity and to the past. The conversion of different parts of the factory into new spaces provided with new functions and in relation to a new institution (the museum) is also suggesting adaptability. The new space being in close connection with the former establishment is actually conveying the idea of continuity and stability.

The other "classical museum," the Musée du Jouet in France also communicates about its building in a manner that enables the "voice of the museum" to be placed in a position of authority and prestige. This authority is expressed by mentioning the local administration that funded the project and but also is also the power and the will of a community supporting this long-term project. Another manner of creating authority is by naming the experts that participated in the construction and design of the building and its permanent exhibition: the architect of the first museum (Guy Bonivard), the two architecture bureau (Blanc Potard and Duboin) responsible for designing and improving the building, and the expert group of museographers - The Kiko Workshop and a multi-disciplinary visual artist Françoise Petrovitch). As to the detailed description of the building, its main purpose is to convey a message about community and collaboration: respect, coherence and harmony - are the words of choice in stressing the development of the museum within its milieu:

“(...) the extension doubled the museum's surface, increasing it to 3400 $\mathrm{m} 2$. The architectural complex is coherent and attractive, and the identity of the site has been renewed while respecting initial options. An east/west axis leading into the town harmoniously federates these spaces with other adjacent activities 5 .

The V\&A Museum of Childhood is privileging narration as a way of presenting its space. However, this narration is deeply embedded, not only with local history (as is the case with the two previous museum), but also with national (Great Britain's) and world history, if we consider the fact that during the 19th century the British Empire led and made possible a series of worldwide changes. The narration about the museum alternates at least three plans: (1) the "official", political history shaped by government authorities and worldwide events such as the International exhibitions; (2) the local history, connected with the Bethnal Green suburb of London, and (3) the museum's history which is linked to both political history and local history. References to the museum building are inserted in all those plans and, therefore, even if there isn't a distinct presentation of the building -

5 http://www.musee-du-jouet.com/en/the-architectural-project accesed on 01.10.2017 
using both pictures and text - one can imagine its atmosphere. There is also a certain circularity of the text: the narrative about the museum begins with mentioning the initial intent of the local gentry that bought the plot where the museum is situated today. It was about preserving some land for feeding the neighboring population. Now, as the author puts it:

"So it is that the V\&A Museum of Childhood at Bethnal Green continues to open its doors daily. In sympathy with the Tudor gentry, this plot of land still feeds the people of East London (and further afield), but as Prince Albert, Henry Cole, W J Wild and other mid-Victorians anticipated, it is their minds that continue to be nourished"6.

Showing (in pictures), narrating and describing are the three techniques used by museum management in order to communicate about its space. However, in conveying different information about the history of the building and its surroundings, the "museum voice" also positions itself as an expert authority. Either by mentioning names and positions of persons having the status of an expert in museum matters, or mentioning the "founding fathers" and "the founding events" - the museum is stressing the idea that knowledge is its authority and power.

\section{Designing virtual space}

The other kind of space constructed by museums is the space of the website and the space of the Facebook page. Therefore, the study first analyzes the website design, in terms of how the information is organized and what content is provided.

The museum websites from France and Spain contain information about: the history of the museum, the collection (composition and history), and representative objects, permanent and temporary exhibitions and proposed activities for children. The Childhood museum in London also includes a new label: learning (which partially corresponds to the categories of activities and exhibitions that we find in another museum).

This way of selecting and displaying information reaffirms a traditional discourse about museums. The information made available to the public contributes to enforcing/confirming the idea about what a museum should be. First and foremost a museum should have its own assets (collection), a history to be shared and it should also propose a series of activities and

6 http://www.vam.ac.uk/moc/about-us/history-of-the-museum/ accessed on 01.10.2017 
learning experiences. History, heritage and learning are the main three attributes emphasized by museum communication via a website.

Permanent exhibitions, and some temporary exhibitions \& activities, are only secondary attributes of an ideal museum. Those secondary attributes are connected to, and even derived from, the main frame history, heritage, and learning. It goes without saying that if you have your own collection of toys, you are supposed to display it in a specific manner: first, by organizing a permanent exhibition and then by organizing temporary exhibitions. However, the only museum that tackles a permanent exhibition as a core characteristic of a museum is the Musée du Jouet in Moirans-en-Montaigne. In addition, this museum is also the only one referring to research and conservation as specific attributes of the museum. The Childhood Museum and the Museo Valenciano del Jugete are also proposing permanent and temporary exhibitions - but they do not emphasize the exhibition per se: they are referring to current activities and collections and the existence of a permanent exhibition is more an agreed convention between the museum and the visitor. The Art Ludique museum is briefly referring to history (better said to the origin of their enterprise), but they do not make any reference to heritage or learning. Art Ludique does not possess a collection of their own and, the learning seems to be replaced by visits and playful activities, conveying the idea of entertainment rather than learning.

As opposed to websites, the interaction space created by Facebook pages is characterized by a form of bidirectional communication. Its specificity, however, lies not in an actual dialogue, but in enforcing the already existing disparity between the museum and its public. One may think that if people are not involved in creating the content on websites, they might be content creators on the Facebook page. However, this is not the case. In their capacity as visitors and Facebook friends, members of the public can create some forms of content, but only in a manner that is filtered and organized by the community administrators. For example, visitors (and especially children) are showed images posted on the website and the Facebook page; also, by taking part in different activities (workshops, volunteer programs, guided tours, toy confectioning), the public participates in the process of creating content for the Facebook page. Of course, that means only images of smiling children will end up on Facebook - so their participation to content creation is filtered. By allowing visitors to participate only in an indirect manner to the process of content producing, the museum, once again, asserts its institutional power over individuals.

The only space where the public is allowed to create content is the space allowed for comments (and reviews) on Facebook. However, the content creation is managed by the institution, firstly by setting the topic of discussion: an exhibition, a contest, or a workshop. Secondly, the community 
manager follows all the comments and from time to time is mixing the institutional discourse with the discourse of individuals. Art Ludique is using this technique of content management: it follows interaction between users and intervenes in the forum, managing content either by responding to direct questions or by ignoring them, as in the example below:

\section{Example $1^{7}$}

"Solange Becker question: everybody stands to win, or a draw will take place afterwards, comprising all the winners?

Art Ludique le musée Hello, the winners will be all those who responded correctly to all the questions, including the subsequent question.

Loulou Town Grégoire Rey

Fatiha Chellali Kweoly $\mathrm{Na}$ ']

Kweoly Na Thank you

Ornella Lorme Will you go there Paloma?

Paloma Cattelan Lome: No, you have already won the WW and, besides, I am not such a great fan

Bérénice Elie Guillemette Cotrie Alezais

François Villechenon And where is the quizzes ${ }^{8}$; ${ }^{2 *}$ pls

Art Ludique le musée Hello, the quiz will be available on site. Have a good evening

François Villechenon Art Ludique le musée Good evening. Agreed. But where is the link for booking $[$ ? ? So I will not play.

Solange Becker a last question: all those items from the picture (whaou) are part of the prize, or is just one of them? $"{ }^{9}$.

A different type of interaction management takes place when the "museum voice" uses intertextuality by mixing its discourse in conversations taking place only between Facebook users. As seen in the previous example, there is a current practice amongst Facebook users to tag their friends in order to invite them to take part in an activity proposed by the museum. Starting with this tagging, small "publically performed conversations" are then developed. Tagging someone on Facebook is a sign of involvement, and the museum is using this involvement in order to tag people when engaging in a conversation with them, although in many cases there is obviously no need to tag them, because participants to this polyphonic conversation have enough context elements as to figure out who the indented recipient of the

8 The translation tried to maintain the grammar used by the Facebook user: the verb is 3rd person singular meanwhile the noun is in plural. 
answer is. The museum is usually blending in the conversation in order to give useful information about the venue or the rules of specific activities, as in examples below. Last, but not least, Facebook users are using various registers of language: they are never formal and quite frequently they neglect orthography and punctuation. The "voice of the museum," on the other hand, is always formal, albeit it tries to convey some casual and friendly feelings to its communication.

\section{Example $2^{10}$}

" Veronique Lombardo I adorrrrred this exhibition

Allisson Francois Hello, where is it situated pls

Veronique Lombardo Near the Austerlitz railway station in Paris

Art Ludique le musée Allisson Francois Hello, the museum Art Ludique is at 34, quai d'Austerlitz 75013 Paris $»^{11}$.

\section{Example $3^{12}$}

Meggie Wayling Nadia Plat I don't know where it's at!

Art Ludique le musée Hello, it is at 34, quai d'Austerlitz 75013 Paris Meggie Wayling Thank you

At this point, some conclusions regarding the management of content and interaction within a given space (static - like the website or dynamic - like the Facebook page) can be drawn. All the instances of communication involving the "voice of the museum" and the online users are placing the museum in a position of power, either by setting the main frame as to what to expect from a museum or by selecting the conversation topic. The museums are in this way asserting their position as a depositary of knowledge, by providing some part of that knowledge (via narratives, descriptions and pictures) to the public, and by using a formal register of address.

\section{Access}

10 Author's translation from French. The original lines are in the appendix.

11 https://www.facebook.com/ArtLudiqueLeMusee post from 8 November 2017

12 Author's translation from French. The original lines are in the appendix.

13 https://www.facebook.com/ArtLudiqueLeMusee post from 8 November 2017 
When communicating online, access is always, in one form or another, limited and there is no need to further insist on limitations generated by age, computer literacy, economy, geographical situation, etc.

Online communication via websites and Facebook pages implies a specific pattern of organizing access. Access means, first, the possibility to read and understand the information made available via the website and Facebook. The Childhood Museum in London is the only museum that doesn't have a web page in a different language than the official language of the country. Art Ludique and the Musée du Jouet in Moirans-en-Montaigne in France, as well as Museo Valenciano del Jugete in Spain, have translated their website into English (not quite entirely although - some nonessential secondary pages are missing, such as "research" or "conservation"). Because it specifically targets Anglophone audiences (by its exhibitions related to the productions of Pixar, Marvel, and Blue Sky studios), Art Ludique makes a further effort in order to translate (using subtitles) in English all the video materials in French that are posted on the website. As a counterpart, all video materials in English (e.g., interviews with cartoons creators) are subtitled in French. Another particularity is to be found in Spain: the website of the museum in Valencia is translated not only into English but also into the local dialect.

Another form of understanding access is programming/coding the site in order to comply with a specific standard. The only museum that has a section that includes a website accessibility statement is the V\&A Museum of Childhood at Bethnal Green.

Interaction on Facebook pages supposes to engage with audiences in a friendly manner that is in a language accessible to them. In France, both museums are communicating in French with other users of Facebook. However, at least in the case of Art Ludique, Facebook users from other countries are using the Facebook page much in the same way as francophone audiences (e.g. tagging friends and engaging in small conversation): the only different thing is the language, as they do not use French but other idioms (e.g., Italian, Dutch). Also, Museo Valenciano del Jugete is once again an exception: its logo on Facebook contains the name of the museum written in local dialect. However, the most of communication is done in Spanish and only one post in 6 (in average) is in the local dialect.

The level of interaction on Facebook is quite low for all museums, except for Art Ludique where interaction consists mainly of tagging friends and asking for practical information (direction, reservation, opening times).

\section{Interpretation and learning}


Interpreting the collections and facilitating the learning process are necessary activities for every museum, and especially for museums dedicated to children and imaginary universes. By interpretation and learning, museums are playing their part in shaping our representations of the world, of plays and toys, on childhood, and finally, they draw upon and reinforce the more extensive system of beliefs and knowledge that govern what counts as right or wrong, good or bad, normal or abnormal, in a particular society.

Providing learning opportunities and creating an environment that enables the learning process seems to be at the core of all activities proposed by museums (Art Ludique is an exception in this respect, but l already discussed its case in a previous section). Learning opportunities are communicated both through the website and Facebook and they refer to opening a new temporary exhibition, late opening hours, organizing a contest, organizing thematic workshops in relation to local celebrations, historical events or "universal" holidays (e.g., Christmas).

However, by carefully following how museums are managing the interaction on Facebook, it becomes clear that they do not want to engage with audiences on social media platforms in order to deliver learning opportunities. They are using Facebook interaction and they create content on the website in order to attract visitors to the real museum (which is, after all, only average). Nevertheless, if museums are to be defined as places of learning, there is an expectation to enforce the learning process both online and offline.

By communicating online, museums are setting an educational agenda and audiences are engaging (or not) with that agenda. An example of how a seemingly "innocent" educational activity is shaping public understanding of the world and is reinforcing specific ideas, comes from the V\&A Museum of Childhood. On the occasion of the 100th commemoration of the Bolshevik Revolution the museum is organizing a lecture announced on Facebook as follows:

\section{Example 4}

"How did the Russian Revolution impact on childhood? Join us on Thurs 16 Nov for an evening of talks by leading academic experts on Soviet history \& culture marking the 100th anniversary of the Russian Revolution. Presentations by leading academic experts will look at the Soviet children's film studio Soiuzdetfilm \& the Society for Co-operation in Russian \& Soviet Studies' incredible children's literature collection, as well as exploring children's literature \& film as an escape from reality"14.

14 https://www.facebook.com/museumchildhood/ post from 01.10.2017. 
Once again we notice how the museum is using the expert as the depositary of knowledge ("leading academic experts"), reinforcing in this way its own status as an expert. However, what is more, interesting is the implicit assumption that children's literature and the film was "an escape from reality" because a Soviet childhood could only be so horrible as to require an escape from reality via books and films. This implicit assumption reaffirms (at least) the pertinence of the old division happy West/unhappy Eastern bloc and the underprivileged position of a Soviet childhood. In addition, when analyzing any given text, it is important to point out the presence of concepts and ideas, their importance and their role within the text; but it is equally important to notice the absence. By referring only to the use that children may have made of books and films, and by not mentioning that, in fact, books and films are designed by adults in order to shape children behavior and minds, much like any other educational item designed for children - the museum is not only ignoring the propagandistic function of such materials, but it is once again reinforcing its own position. After all, museums are never ideologically neutral and saying that children's books were propaganda is equal to saying that behind every book for children there must be an agenda (not necessarily a political one).

Analyzing the Facebook pages and the websites, specific patterns/models may be observed in the way museums are approaching the idea of "learning." There is a British model, which is truly emphasizing learning by the way the website is organized (The V\&A Museum's website has a dedicated section for "learning"). On Facebook, The V\&A Museum is also enforcing learning: it is the only museum that, besides communicating about activities and events, is also communicating about rare items from their collections, thus providing further education about the museum's assets. On the other hand, the French model (illustrated by Musée du Jouet in Moirans-en-Montaigne) is noticeable because it takes particular care to provide useful information for parents and educators, in order to facilitate the learning process (at the museum).

\section{CONCLUSION}

\section{Creating social identities and social practices through communication management}

With museums entering the digital era, more things have changed than having the opportunity to buy tickets online or to make a virtual tour of an exhibition. There are indeed domains specific to the "digital museum" (keeping up to date records of collections, having a digital inventory, digitizing collections - especially books and other valuable documents) where museums are 
often challenged by the lack of resources or by the lack of trained personnel. However, in communicating the museum as a whole, its mission, its attributes, in constructing its own narrative and its own space or in enforcing learning the museum has got a powerful management tool. By managing the content of communication and by managing the online interaction, a museum is reasserting its social identity as a place of knowledge and as a place of power. It also creates a social role for its visitors: the museum proposes activities, workshops, charitable events, concerts, even free debates (on a set topic, related to the activity of the museum of course). The visitor (or the potential visitors, the Internet user accessing the website or the Facebook page) has its role well defined, always being at the receiving end of the museum wisdom and knowledge. In terms of social practices, by managing the preliminary with a potential visitor, the museum is preparing the prospective visitor to act out its role. The visitor's expectations are set, and the overall context of the future visit to the museum is already conveyed via online communication. Therefore, the social practice that consists of going to a museum to spend some leisure time and to perform a learning activity is rehearsed, and in this way reinforced, by online communication.

By providing content (for the online communication) and also by engaging in online interaction, museums are performing (or they could perform) an essential phase of any management plan: the execution of their mission. As textual analysis revealed, both content management and interaction management are instrumental in constructing social identities and social practices.

\section{Appendix - original text in French}

\section{Example 1}

"Solange Becker question: tout le monde peut gagner ou est-ce ensuite un tirage au sort parmi les gagnants ?

Art Ludique le musée Bonjour, les gagnants seront ceux qui auront bien répondu à toutes les questions, y compris la question subsidiaire $\stackrel{*}{*}$;

Loulou Town Grégoire Rey

Fatiha Chellali Kweoly Na [?],

Kweoly Na Merci

Ornella Lorme Y irais-tu Paloma?

Paloma Cattelan Lome : Non tu as déjà gagné WW puis je ne suis pas une grande fan

Bérénice Elie Guillemette Cotrie Alezais

François Villechenon Et ou est le questionnaires? ;) ${ }^{*}$ svp 
Art Ludique le musée Bonjour, le questionnaire vous sera remis sur place. Bonne soirée

François Villechenon Art Ludique le musée bonsoir. D'accord d'ou le lien pour réservé ${ }^{\prime}$ ? ! Donc je ne jouerais pas

Solange Becker une dernière question : est-ce tout le lot (whaou) ou uniquement l'un des cadeaux sur la photo ? ${ }^{15}$

\section{Exemple 2}

« Veronique Lombardo J’ai adorrrrrré cette expo

Allisson Francois Bonjour elle se passe situe ou svp

Veronique Lombardo Près de la gare d'austerlitz à Paris

Art Ludique le musée Allisson Francois Bonjour, le musée Art Ludique est au 34, quai d'Austerlitz 75013 Paris ${ }^{16}$.

\section{Exemple 3}

Meggie Wayling Nadia Plat je sais pas où c'est !

Art Ludique le musée Bonjour, c'est au 34, quai d'Austerlitz 75013 Paris

Meggie Wayling Merci

\section{References}

Badell, J. -I. (2015). Museums and social media: Catalonia as a case study. Museum Management and Curatorship, 30(3), 244-263.

Brookshaw, S. (2009). The material culture of Children and childhood. Understanding childhood objects in the museum context. Journal of Material Culture, 14(3), 365-383.

Burton, A. (1997). Design history and the history of toys: Defining a discipline for the Bethnal Green Museum of Childhood. Journal of Design History, 1(1), 1-21. Capriotti, P., \& González-Herrero, A. (2013). Managing media relations in museums through the Internet: A model of analysis for online pressrooms in museums. Digital Heritage, 28(4), 413-429.

Capriotti, P., \& Kuklinski, H. P. (2012). Assessing dialogic communication through the Internet in Spanish museums. Public Relations Review, 38(4), 619-626.

Duriau, V. J., Reger, R. K., \& Pfarrer, M. D. (2007). A content analysis of the content analysis literature in organization studies: Research themes, data sources and methodological refinements. Organizational Research Methods, 1(10), 5-34.

15 https://www.facebook.com/ArtLudiqueLeMusee, post from 15.11.2016.

$16 \mathrm{https} / / /$ www.facebook.com/ArtLudiqueLeMusee post from 8 November

17 https://www.facebook.com/ArtLudiqueLeMusee post from 8 November 2017. 
Fairclough, N. ( 2003). Textual Analysis for Social Research. London: Routledge. Gilmore, A., \& Rentschler, R. (2002). Changes in museum management: A custodial or marketing emphasis? Journal of Management Development, 21(10), 745-760,

Girveau, B., \& Charles, D. (2011). Des jouets et des Hommes. Paris: Reunion Des Musees Nationaux.

Halliday, M. K. (1978). Language as Social Semioti: The Social Interpretation of Language and Meaning. London: Edward Arnold.

Hooper Greenhill, E. (1992). Museums and the Shaping of Knowledge. London: Routledge.

Jones, R. H. (2012). Discourse Analysis: A Resource Book for Students. London: Routledge English Language Introductions.

Liu, C.-R., Liu,. H.-K., \& Lin, W.-R. (2015). Constructing customer-based museums brand equity model: The mediating role of brand value. International Journal of Tourism Resources, 17(3), 229-238.

Mayfield, M. I. (2005). Children's museums: Purposes, practices and play?. Early Child Development and Care, 175(2), 179-192.

Pary, R. (2010). Museum in a Digital Age. London: Routledge.

Poulot, D. (2005). Une histoire des musées de France, XVIIle-XXe siècles. Paris: La Découverte.

Poulot, D. (2009). Musée et muséologie. Paris: La Découverte.

Richardson, J. (2007). Analysing Newspapers: An Approach from Critical Discourse Analysis. New York: Palgrave Macmillan.

\title{
Websites and Facebook pages
}

Art Ludique http://www.artludique.com/musee2.html, https://www.facebook.com/ArtLudiqueLeMusee

Musée du Jouet in Moirans-en-Montaigne http://www.musee-du-jouet. com/ https://www.facebook.com/Musee.du.jouet.moirans

V\&A Museum of Childhood at Bethnal Green http://www.vam.ac.uk/moc/ https://www.facebook.com/museumchildhood/

Museo Valenciano del Jugete http://www.museojuguete.com/en/ https:// www.facebook.com/museo.deljuguete.1

\begin{abstract}
Abstrakt
Muzea, poprzez swoje dyskursy instytucjonalne, odgrywajq ważnq, ale czasami zaniedbanq rolę $w$ egzekwowaniu praktyk społecznych i tworzeniu tożsamości społecznej. Wraz z nowq cyfrowa erq, muzea musiały dostosować się do nowych form komunikacji: w środowisku, które, przynajmniej pozornie, daje każdemu równy głos, muzea zdołały się porozumieć, nie rezygnujq̨ z pozycji depozytariuszy wiedzy i auto-
\end{abstract}


rytetu. Analizujq̨ komunikację online, zarzq̨dzanie treściq i zarzqdzanie interakcjami (na stronach internetowych, na stronach Facebooka), obecne badanie ma na celu zbadanie mechanizmów umożliwiajqcych muzeom przekazywanie informacji o ich specyficznych cechach (przestrzeń, dostęp, uczenie się i interpretacja), zachowujq̨c jednak głównq rolę jako komunikatora, ale także jako aktora wzmacniajqcego system wierzeń i wiedzy, który rzq̨dzi tym, co uważa się za poprawne, niepoprawne; dobre lub złe, normalne lub nienormalne $w$ danym społeczeństwie. Tak więc, łączqc komunikację postrzeganq jako narzędzie zarzq̨dzania i analizę tekstowq, niniejsze badanie ilustruje zastosowanie różnych jakościowych metod badawczych $w$ dziedzinie zarzqdzania, a w szczególności w dziedzinie zarzqdzania komunikacjq.

Słowa kluczowe: muzeum zabawek, zarzqdzanie komunikacjq, zarzqdzanie treściq, analiza tekstowa.

\section{Biographical note}

Monica Bîră, Ph.D., is Lecturer at the National University of Political Studies and Public Administration, Romania, where she teaches image studies and crisis communication. She defended her Ph.D. thesis at the University of Bucharest with a study on national identity and the social construction of heritage. Her research is focused on social representation and the way public interaction is shaping cultural heritage, constructing representations of the past and/or influencing the definition of otherness. 